\title{
THE DEFORMATION OF LANGUAGE AND NEW BIRTH OF THE MYTH
}

\author{
O.N. Strelnik \\ Peoples' Friendship University of Russia (RUDN University) \\ 6, Miklukho-Maklaya St., 117198, Moscow, Russian Federation
}

\begin{abstract}
The re-mythologizing of modern culture, that is the return of archaic myths and professional mythmaking to arts, politics, advertising and mass communications, transferred the academic problem of myth to the category of topical issues. To study this "new" mythological consciousness, it is essential to know the structure of classical myth. This article will examine a theoretical perspective on the problem of myth and the mythical - the concept of myth in relation to language proposed by the French philosopher and literary critic Roland Barthes. Special subject of this article - the relation of the modern myth and language, similarity and distinction of archaic mythological and the modern mythologized mass thinking.
\end{abstract}

Key words: Myth, rational thinking, mythological thinking, language, communications, semiological system, signs, meta-language, connotation, archaic myth, modern mythmaking, images, modern myth

\section{INTRODUCTION}

Myth is back in a new garb and with new features. This is the conclusion to which many philosophers, culture scholars and psychologists came by the end of the last century. The 20th century demonstrated that rational thinking is not the only way for the mind to conceive the world and that it does not cancel the phenomenon of collective consciousness being mythologized. In the grand scheme of things, myth never left; however, it changed its appearance to become one of the most important cultural forms of the $20^{\text {th }}$ century.

The re-mythologizing of modern culture, that is the return of archaic myths and professional mythmaking to arts, politics, advertising and mass communications, transferred the academic problem of myth to the category of topical issues. To study this "new" mythological consciousness, it is essential to know the structure of classical myth. However, this would not be enough, as modern mythological thinking goes way beyond the archaic forms. In addition to the revival of archaic myth in contemporary culture, new phenomena have emerged. On the one hand, they possess the intrinsic characteristics of myth; on the other hand, they have assimilated the latest achievements of philosophy, science, religion, and art. The distinctive features of these "new archaic" phenomena provoke some researchers to equal modern collective consciousness with the myth.

All these circumstances ask for the analysis of mythological thinking in its current state, and, probably, for a new interpretation, if not an extension, of this concept.

At the beginning of the 20th century, myth was revived by writers who created one of the century's prominent cultural phenomena - neo-mythologism. Major writers start- 
ed using mythological story arcs and forms in their work. In this instance, literature itself is likened to myth through mythological heroes disguised as "normal' characters, cyclical time, language play, and lack of boundaries between illusion and reality. Suffice it to recall Ulysses by James Joyce, The Castle by Franz Kafka or Master and Margarita by Mikhail Bulgakov.

Anthropologists, followed by semioticians and philosophers, deemed myth to be the main subject of their theoretical interests. The 20th century presented more than a dozen approaches to the problem of myth and the mythical. Lucien Lévy-Bruhl introduced the ethnographic theory of myth; Bronisław Malinowski and James Frazer regarded myth from the ritualistic perspective; Ernst Cassirer studied the symbolic meanings of myth; Sigmund Freud and Carl Gustav Jung viewed it through psychoanalysis; Claude Lévi-Strauss represented the structuralist school of thought; Roland Barthes and Michel Foucault used the poststructuralist approach. In Russia, Vladimir Propp, Olga Freidenberg, Mikhail Bakhtin and Aleksei Losev played an enormous role in exploring the problem of myth. The theoretical and artistic "revival" of myth was a kind of reaction to the positivist consciousness of the second half of the 19th century.

This article will examine a theoretical perspective on the problem of myth and the mythical - the concept of myth in relation to language proposed by the French philosopher and literary critic Roland Barthes. In his book, pointedly named Mythologies, Barthes almost defiantly rejects the earlier academic theories of myth by Frazer, Cassirer, Jung and Lévi-Strauss. However, it would be wrong to say that he completely breaks with the philosophical tradition. On the one hand, Barthes bases his analysis on the philosophical principles of structuralism, i.e. he analyses stable structures, regardless of the "matter" where they are found; on the other hand, he uses the poststructuralist and postmodernist philosophical postulates. Barthes understands the reality, both cultural and natural, as a set of symbolic systems of various kinds, which should be read and decrypted, and in the case of myth - debunked and demystified. Such ambiguity of the theoretical perspective is characteristic of the entirety of Barthes' work. Mythologies is "a fine example of this irreducible polynuclearity. Any attempt to "straighten" it according to some ideological concept... will inevitably lead to simplification" [7. P. 5].

\section{THE MODERN MYTH IS THE SPEECH "STOLEN"}

In spite of its complexity and ambiguity, Barthes' framework can still be considered semiological. In his opinion, "it is far from certain that in the social life of today there are to be found any extensive systems of signs outside human language" [3. P. 115]. This principle also applies to myth. Myth is a special semiological system — it is a secondary semiological system brought to life because of natural language distortion.

Barthes himself declares his theoretical goal: to define contemporary myth from the methodological standpoint. In this light, the most interesting part of Mythologies is the so-called "theoretical afterword", i.e. the second part, which provides the conceptualization of myth. The first part, or the so-called "practical mythologies", contains a wealth of illustrative material, reinforcing the analytical findings of Barthes. 
Barthes analyzes the world of advertising and mass communications, them being the focus of modern myth. This world simultaneously annoys the French philosopher and sparks his interest. His theoretical attention is captured by modern myth, or rather by modern collective consciousness. To this subject he relates his findings. "One can... imagine a diachronic study of myths, whether one submits them to a retrospection (which means founding a historical mythology) or whether one follows some of yesterday's myths down to their present forms (which means founding prospective history). If I keep here to a synchronic sketch of contemporary myths, it is for an objective reason: our society is the privileged field of mythical significations" [2. P. 264].

The modern myth is a secondary semiological system, which is formed by the distortion of natural language — the primary system. Any message can become myth. "Myth is a system of communication, ... a message ... it is a mode of signification, a form ... everything can be a myth provided it is conveyed by a discourse. Myth is not defined by the object of its message, but by the way in which it utters this message" [2. P. 233]. "Myth is speech stolen and restored. Only, speech which is restored is no longer quite that which was stolen: when it was brought back, it was not put exactly in its place" [2. P. 252].

Myth shifts and distorts the meaning of natural language signs, with the primary sign being merely a new means of expressing a new mythical sense. In other words, Barthes' myth is a connotation. Nevertheless, the philosopher calls it a metalanguage. This is one of the inconsistencies and inaccuracies, for which he was criticized by both semioticians and linguists. Barthes declares that "in myth there are two semiological systems, one of which is staggered in relation to the other: a linguistic system, the language (or the modes of representation which are assimilated to it), which I shall call the language-object, because it is the language which myth gets hold of in order to build its own system; and myth itself, which I shall call metalanguage, because it is a second language, in which one speaks about the first" [2. P. 240]. However, the generally accepted meaning of the term meta-language is different. Metalanguage is a secondary system of signs, by the means of which the properties of the primary language-object are studied and described. At the same time, connotation is seen as the imposition of additional meanings upon the original message, while distorting or at least changing it. Barthes examines the way the distortion of the original meaning takes place, i.e. talks about myths as connotations. However, contrary to his own theoretical conclusions, he continues to call myth a meta-language. Only in his later work, Elements of Semiology, he brought his terminology in line with what is generally accepted in modern theoretical linguistics.

Barthes' myth analysis begins with a discussion of natural language, which provides the basis for myth (or the mythical) in most cases. A sign of the primary semiological system is the unity of signifier and signified. The signified is the object or phenomenon expressed with the sign, while the signifier is the form of expression. The meaning of the sign arises from the unity of the signifier and the signified, i.e. the form and the content. However, according to Barthes, any semiological system contains not just 
these two elements, as it is postulated by classical semiology — it has three of them: "It is as true to say that on the plane of experience I cannot dissociate the roses from the message they carry, as to say that on the plane of analysis I cannot confuse the roses as signifier and the roses as sign: the signifier is empty, the sign is full, it is a meaning" [2. P. 237-238]. Barthes insists that this distinction between signifier and signified is extremely important in the study of myth.

Myth is a semiological system as well. However, an original sign from the primary language system becomes the signifier there. It is the form, which is on the one hand empty as any form, and on the other hand not free from the original semantic content specified by the primary language system. This mechanism of "emasculating" the meanings of natural language goes as follows. "The meaning is already complete, it postulates a kind of knowledge, a past, a memory, a comparative order of facts, ideas, decisions. When it becomes form, the meaning leaves its contingency behind; it empties itself, it becomes impoverished, history evaporates, only the letter remains. There is here a paradoxical permutation in the reading operations, an abnormal regression from meaning to form, from the linguistic sign to the mythical signifier. ... But the essential point in all this is that the form does not suppress the meaning, it only impoverishes it, it puts it at a distance, it holds it at one's disposal. One believes that the meaning is going to die, but it is a death with reprieve; the meaning loses its value, but keeps its life, from which the form of the myth will draw its nourishment" [2. P. 242-243]. The signifier of myth has the form present in its emptiness and the meaning absent in its fullness. As a result, the signifier of the mythological system becomes the indisputable and incontestable paragon, which is "read" by the myth consumer in its entirety, being emasculated at the time of its mythical transformation.

The signified of myth is not the reality itself, as it is the case in the original linguistic system, but some emotionally rich, blurred and vague idea of reality. It is rather a chain of uncertain but emotionally charged associations than a precise and clear notion. "In actual fact, the knowledge contained in a mythical concept is confused, made of yielding, shapeless associations. One must firmly stress this open character of the concept; it is not at all an abstract, purified essence; it is a formless, unstable, nebulous condensation, whose unity and coherence are above all due to its function" [2. P. 244].

\section{PHILOSOPHICAL "READING" THE MYTH IS THE DECODING AND ANALYTICAL DEBUNKING}

Thus, modern myth unifies the indisputable image (form) and the emotionally saturated indisputable representation (meaning). The third element of Barthes' mythological system is called "concept". However, in our opinion, it would be more accurate to call it a symbol, which, unlike a sign of the primary language system, carries an infinite number of meanings. That is why, by the way, myth can never be read literally.

Barthes notes that the structure "signified - signifier — sign" can be found in natural language (Ferdinand de Saussure's theory), where it looks like the triad "concept psychoacoustic image - word". The same structure is studied in psychoanalysis (Sig- 
mund Freud's theory). There this semiological triad is represented as the literal content of a dream (an act or a neurotic experience), its explicit content and the dream (the act or the experience) itself in its entirety.

Myth has the task to convey intention, suggestion or motivation to action, rather than to broadcast information. "Myth hides nothing and flaunts nothing: it distorts; myth is neither a lie nor a confession: it is an inflexion. ... Entrusted with 'glossing over' an intentional concept, myth encounters nothing but betrayal in language, for language can only obliterate the concept if it hides it, or unmask it if it formulates it" [2. P. 255]. Myth has impression-based character and value-based nature, which makes its impact stronger than that of any rational rebuttal or argument.

Myth has now been analyzed, and it is time to decipher it. According to Barthes, the essence of this reflexive procedure is to identify the original representation (the signified) under the different guises (the signifiers) appearing in the myth. Since modern myth is constructed artificially, it can certainly be decrypted - yet in a more quick and efficient manner than in the case of archaic myth. Barthes offers three ways of "reading" myth; however, the decoding and analytical debunking is possible with just one of them.

The first method can be called naive, since it is the way myth is treated by its consumer. A naive reader of myth directly experiences it and, seeing no trick, gives in to the hidden intentions: "the reader lives the myth as a story at once true and unreal" [2. P. 254]. Such person perceives it not as an axiological but as an actual system. In this case, the signified and the signifier are connected as cause and effect. Nevertheless, myth does not imply cause-and-effect relationships - it has only analogies and equivalences. In myth, the nature of things is doubled, i.e. objects and phenomena as they exist in and of themselves are enhanced with additional semantics. Myth provides a set of implicit cultural codes, which are read by the myth consumer. The naive consumer who feels comfortable in the labyrinth of constructed and illusory meanings is the main carrier of myth. The enchanting completeness and aesthetic thoroughness makes myth attractive, which is why freedom is exchanged for myth without regrets or doubts. However, the completeness, clarity and completeness of myth are illusory; it only states things, but never explains anything.

The second way to treat myth is to construct it. This is the position of the mythmaker who looks for a suitable signifier to match a mythological signified. The more talented the mythmaker is the more vivid and suggestive the signifier proves to be.

The third way to approach myth (which is the only rational one as far as Barthes is concerned) is to perceive it as a distortion. This is the way a scientist or a philosopher treats it, distinguishing the content and the form — the signified and the signifier and thus detecting the substitution of natural language meanings. Barthes himself uses this very method in Mythologies. "If I focus on a full signifier, in which I clearly distinguish the meaning and the form, and consequently the distortion which the one imposes on the other, I undo the signification of the myth, and I receive the latter as an imposture" [2. P. 254]. However, according to Barthes, no modern man is ever completely 
and utterly free from myth; everyone is susceptible to its charm and suggestion at least occasionally.

Paradoxically, Barthes criticizes myths and mythmaking, saying that the best weapon against myth is mythologizing it. "Since myth robs language of something, why not rob myth? All that is needed is to use it as the departure point for a third semiological chain, to take its signification as the first term of a second myth. ... The power of the second myth is that it gives the first its basis as a naivety which is looked at" [2. P. 262]. Building second-order myths is an artistic activity, and fiction provides us with samples of such "mythologizing of myth". In this sense, Barthes discusses the works of Gustave Flaubert and Jean-Paul Sartre. The Russian writer Vladimir Sorokin provides another example of the artistic design of artificial myths. By placing the "myths" of the classical Russian literature in different contexts, he destroys the illusion of clarity, naivety and "naturalness", revealing the concealed contradictions and showing the undercurrent axiology.

In Barthes' theory, myth possesses the features of art, ideology, religion, science, and other cultural forms. It is aesthetically pleasing as an object of art, intellectually clear as a political ideologeme and emotionally doubtless as a religious experience. Barthes' myth is omnipresent and inevitable, and the whole of modern culture is mythological. However, by turning myth into the totality and identifying it with the whole popular culture, Barthes thereby dissolves the essence of myth in other cultural forms, and as a result, loses the object of his theorizing. For all the conceptual novelty of his theory, modern myth is interpreted too broadly, coinciding with any semantic deformations of a natural language. However, it is hardly legitimate to consider any play on meanings or any manipulation with uncertain and emotionally saturated images to be myth.

Predisposition to myth that is to a connotative deformation is inherent in natural language, says Barthes. The language's expressiveness and figurativeness, as well as its inability to convey things simply and in a "non-imaginative" way, determinates the possibility of a mismatch between the signified and the signifier. Only a language with zero-degree imagery could resist myth. In our view, in developing this thesis, Barthes makes a mistake in his reasoning, namely, ignoratio elenchi. The natural language, indeed, does not leave the possibility to express things in a "non-imaginative" way, as the minimum degree of imagery accompanies even a rigorous scientific discourse. However, expression and imagery should not be equated to the mythological, just as any kind of imaginative thinking should not be equated to mythological thinking.

At the heart of mythological thinking lies the ability of consciousness to produce and handle images; however, not any kind of thinking based on images rather than on logical concepts should be called myth. Modern psychology identifies different kinds of thinking, such as concrete operatory, image, abstract, not referring to myth and mythological thinking. The latter is still a special type of mental activity, with its own characteristics and properties, and in the case of primitive mythological consciousness and modern mythologized consciousness, these properties can vary. 
The imprecision and vagueness of meaning also characterize a linguistic expression, and Barthes calls this the abstractness of linguistic concepts. The linguistic expression, placed in a new context, acquires different shades of meaning. "One could say that a language offers to myth an open-work meaning. Myth can easily insinuate itself into it, and swell there: it is a robbery by colonization ... When the meaning is too full for myth to be able to invade it, myth goes around it, and carries it away bodily" [2. P. 258 - 259]. In our opinion, the very same error is repeated here: the thesis is constricted on the basis of insufficient arguments. The Reformation period scholars already talked about the possibility of playing on meanings depending on the context of word use. For instance, as early as in $16^{\text {th }}$ century, Matthias Flacius Illyricus argued that when studying texts, one should take the context of words into account. The original meaning of the word is one thing, but its use in different contexts provides it with new shades of meaning and reveals its hidden possibilities. However, not every play on meanings gives rise to myth, contrary to Barthes' assertions.

The language of popular culture and modern collective consciousness is hardly mythological overall, as it is claimed by the French philosopher. However, his critique of the language of mass culture, and his take on the nature of the connection between myth and language do not evoke any doubts, and neither does his well-founded allegation about modern myth being secondary in relation to other cultural forms.

\section{THE MYTH SET ON A PEDESTAL: ARCHAIC MYTH AND MODERN MYTHMAKING}

In modern culture, myth has ceased to be a spontaneous activity of the unconscious mind and a free play of imagination. Modern myth is, on the one hand, the tamed myth created at the whim of myth-makers and, on the other hand, the myth set on a pedestal. Constructed and secondary, modern myth is at the same time almost omnipotent. Not only unsuspecting citizens watching TV or listening to the radio, but also the mythmakers themselves are under its authority. It is worth remembering Ernst Cassirer, another philosopher of the 20th century, who writes that the modern myth is a chimera born by cross-breeding the traditional elements of myth with the phenomena of technology and public authorities. The only way to fight this monster is to drop the blinkers of fear and propaganda and to learn its habits. The question is whether modern people can do it. For Barthes, myth is an illusion and a self-deception of the spirit - completely irresistible in this regard.

There are valid reason to disagree with Barthes' pessimism: having been constructed, myth therefore can be decrypted, and after that, its power vanishes. The limitation of modern myth is its fundamental difference from archaic myth. Modern myth is not the primary experience of an archaic person he or she lives through - the experience with which alone the reality is revealed. This experience is secondary, and a modern person plunges into it, as such as the nature of his or her mind. However, this secondary experience can be discharged.

What is common between ancient mythical thinking and modern mythologized consciousness? To understand the nature of archaic consciousness and the features of 
modern mythmaking, it is worth remembering some ideas of Carl Gustav Jung. He distinguishes between two modes of thinking: directed (logical) and fantasy thinking (a way of unconscious information processing). Unconscious thinking is the proto-form of logical thinking, which appears as a result of its development. Directed logical thinking is in many ways an element of one's profession. Meanwhile, everyday thinking — which exists on the level of ideas rather than of logical concepts and has the form of free and non-directed movement of thought - is an element of everyday life. The main motivating force of this kind of thinking is not logic, but emotion and desire. A person fantasizes about what he or she lacks, and such semi-conscious thinking produces the images that express possible and desired future. As far as objectivity is concerned, these images may be unrealistic, but they are absolutely real from the standpoint of subjectivity and emotion.

Archaic myth and modern mythmaking are different phenomena, although generated by the same type of consciousness, that is, the imaginative consciousness with its specific logic of binding events and things. The imaginative consciousness provides the emotional perception of reality and the recognition of faces and voices. As the modern mind has this "imaginative part", it is still possible to revive the mythological. Modern human consciousness is not fully emancipated from its archaic roots; hence, the mythmaking ability cannot be eliminated completely. The production of images, including mythological ones, is always carried out in parallel with intellectual activity. It is this type of thinking that serves as the basis for the formation of modern myths. However, the unconscious mind and mythological thinking cannot be equaled. You can definitely say that mythological thinking (modern or archaic) is unconscious and imaginative by its nature. Nevertheless, it would be a mistake to say that any kind of unconscious thinking is mythological.

Collectivity is a key term in the description of any myth, ancient or modern. In relation to modern myth, collectivity acquires the implication of massive participation. As far as the psychological mechanism is concerned, myth functions in the modern mind just as it did in the primitive mind. The modern mythmaking is based on collective representations, which are almost as resistant to the pressure of experience as the primitive myth used to be. Most would rather deny their experience than the solid collective representation, which it contradicts. A person does not see the world as it is given in their direct experience; immediacy, in this sense, is rather an illusion. Archaic myth provides a primitive man with the coordinate system for the perception of the world, and the perception adapts to the "mythological grid". The same can be said about modern collective consciousness. It exists in the markup, set by tradition or created by professional myth-makers. A modern person believes in this or that generally accepted truth like as a prehistoric one did; those ideas are an essential condition for one's existence in the culture.

Both modern myth and ancient myth are value-based by nature, but at the same time, there are significant differences between them. Archaic mythology is a unified system in which fundamental cultural oppositions are developed and resolved. The purpose of traditional myth, as Lévi-Strauss writes in Structural Anthropology, is "to give 
a logical model for resolving a certain contradiction" [12. P. 206]. Primitive mythology provides a kind of aprioristic system of values, which enables a primitive man to navigate both natural and social worlds. It is a benchmark and a frame of reference of sorts; therefore, it is appropriate to argue that an archaic person lives through myth and not just knows about it.

Modern myths, in contrast to archaic ones, are not easy to be framed in a unified system. They serve neither the resolution nor the eradication of conflicts, but only expose them to "'spell' and justification, remaining a mostly nominal rather than verbal discourse ... they thereby stay connected with the mythological culture of Name; however, their multiplicity, unsystematic character and lack of plot make their own artistic expression impossible" [7. P. 16]. Contemporary myth denies nothing and explains nothing - it merely states. It creates an illusion of clarity and naturalness, but this clarity is illusory, as contemporary myth goes no further than the immediate visibility. In contrast to archaic myth, built as a continuous and cohesive narrative, modern myth is discrete; it is expressed not in large narrative forms but as a set of phrases and stereotypes.

The source of archaic myth is the whole life of ancient people, while the source of modern myth lies in anonymous and still widely held beliefs instilled in childhood and difficult to reflect upon. In other words, primitive myth is a mirror of reality in the minds of ancient people. It is the original form of spiritual culture, or, as Hans-Georg Gadamer puts it, the "proto-thought" of humanity. In contrast, modern myth is a reflection of something already reflected in the culture - a kind of barrier between consciousness and reality, which is not recognized by this consciousness and is not considered, at least at the everyday level. "It is therefore by no means confined to oral speech. It can consist of modes of writing or of representations; not only written discourse, but also photography, cinema, reporting, sport, shows, publicity, all these can serve as a support to mythical speech. Myth can be defined neither by its object nor by its material, for any material can arbitrarily be endowed with meaning... Mythical speech is made of a material, which has already been worked on to make it suitable for communication... pictures, to be sure, are more imperative than writing; they impose meaning at one stroke, without analyzing or diluting it. But this is no longer a constitutive difference. Pictures become a kind of writing as soon as they are meaningful... a photograph will be a kind of speech for us in the same way as a newspaper article; even objects will become speech, if they mean something" [2. P. 234-235].

In addition, here is one more fundamental difference between modern and archaic myths. Primitive myth is plenary: it is not simply there - it dominates the minds of prehistoric people. Modern myth does not occupy all the expanse of one's consciousness. It can be reflected upon and thus overcome. It is wrong to identify of the whole sphere of contemporary collective representations to myth.

\section{CONCLUSION}

Thus, modern myth unifies the indisputable image (form) and the emotionally saturated indisputable representation (meaning). The third element mythological system is a symbol, it carries an infinite number of meanings. That is why myth can never be 
«read» literally. Barthes' myth is omnipresent and inevitable, and the whole of modern culture is mythological. For all the conceptual novelty of his theory, modern myth is interpreted too broadly, coinciding with any semantic deformations of a natural language. However, it is hardly legitimate to consider any play on meanings or any manipulation with uncertain and emotionally saturated images to be myth. Both modern myth and ancient myth are value-based by nature, but at the same time, there are significant differences between them. Modern myths, in contrast to archaic ones, are not easy to be framed in a unified system. They serve neither the resolution nor the eradication of conflicts. Contemporary myth denies nothing and explains nothing - it merely states. It creates an illusion of clarity and naturalness, but this clarity is illusory, as contemporary myth goes no further than the immediate visibility. In contrast to archaic myth, built as a continuous and cohesive narrative, modern myth is discrete; it is expressed not in large narrative forms but as a set of phrases and stereotypes. However, we have to agree with Barthes: in contemporary culture "myth in and of itself disappears, but the mythical, which is even more insidious, stays" [1. P. 79].

(C) Strelnik O.N., 2017

\section{REFERENCES}

[1] Barthes R. Le bruissment de la langue. Paris, 1984.

[2] Barthes R. Mythologies. Moscow, 2000. (In Russ).

[3] Barthes R. Semiologiya bases. Structuralism: pros and cons. Moscow, 1975. (In Russ).

[4] Bahtin MM. Esthetics of verbal creativity. Moscow, 1986. (In Russ).

[5] Bulgakov MA. Master and Margarita. Moscow, 2005. (In Russ).

[6] Joyce J. Ulysses. Moscow, 1993. (In Russ).

[7] Zenkin SA. R. Barthes - theorist and practician of mythologies. Barthes R. Mythologies. Moscow, 2000. (In Russ).

[8] Cassirer E. Technology of modern political myths. Bulletin MSU. Series Philosophy. 1990; (2). (In Russ).

[9] Cassirer E. Philosophy of symbolical forms. 3 v. Moscow, St. Petersburg, 2002. (In Russ).

[10] Kafka F. The castle. Rostov-na-Donu, 1999. (In Russ).

[11] Lévy-Bruhl L. Supernatural in primitive thinking. Moscow, 1999. (In Russ).

[12] Levi-Strauss C. Anthropologic structurale. Moscow, 2001. (In Russ).

[13] Losev AF. Antique mythology in her historical development. Moscow, 2005. (In Russ).

[14] Malinowski B. A Scientific Theory of Culture. Moscow, 2005. (In Russ).

[15] Propp V. Historical roots of the magic fairy tale. Moscow, 1998. (In Russ).

[16] Sorokin V. Works in 2 Vol. Moscow, 1998. (In Russ).

[17] Frejdenberg OM. Poetics of a plot and genre. Moscow, 1997. (In Russ).

[18] Frazier J. The Golden Bough: A Study in Magic and Religion. Moscow, 1983. (In Russ).

[19] Freud S. Totem and taboo. Moscow, 2005. (In Russ).

[20] Foucault M. Will to the truth: on that side of knowledge, the power and sexuality. Moscow, 1996. (In Russ).

[21] Jung CG. Archetype and symbol. Moscow, 1991. (In Russ).

[22] Jung CG. God and unconscious. Moscow, 1998. (In Russ).

[23] Jung CG. Psychological types. Moscow, 1995. (In Russ). 


\title{
ТРАНСФОРМАЦИЯ ЯЗЫКА И НОВОЕ РОЖДЕНИЕ МИФА
}

\author{
О.Н. Стрельник \\ Российский университет дружбы народов \\ 117198, Москва, Россия, ул. Миклухо-Маклая, д. 6
}

\begin{abstract}
Ремифологизация современной культуры, возвращение архаичных мифов и профессиональное мифотворчество в искусстве, политике, в традиционных СМИ и так называемых новых медиа переводит академическую проблему мифа в разряд актуальных проблем. Чтобы изучить это «новое» мифологическое сознание, важно знать структуру классического мифа. Эта статья исследует теоретический взгляд на проблему мифа и мифического, предложенную французским философом и литературным критиком Роландом Бартом. Специальный предмет этой статьи - отношение современного мифа и языка, подобие и различие современного и архаичного мифа.
\end{abstract}

Ключевые слова: миф, рациональное мышление, мифологические представления, язык, семиологическая система, метаязык, коннотация, архаичный миф, современное мифотворчество, современный миф

\section{ЛИТЕРАТУРА}

[1] Barthes Roland Le bruissment de la langue. Paris, 1984.

[2] Барт Р. Мифологии. М.: Издательство имени Сабашниковых, 2000.

[3] Барт Р. Основы семиологии // Структурализм: «за» и «против». М.: Искусство, 1975.

[4] Бахтин М.М. Эстетика словесного творчества. М.: Искусство, 1986.

[5] Булгаков М.А. Мастер и Маргарита. М.: Эксмо, 2005.

[6] Джойс Дж. Улисс. М.: Республика, 1993.

[7] Зенкин С.А. Ролан Барт - теоретик и практик мифологии // Вступительная статья к кн. Барт Р. Мифологии. М.: Издательство имени Сабашниковых, 2000.

[8] Кассирер Э. Техника современных политических мифов // Вестник Московского университета. Серия 7. Философия. 1990, N 2.

[9] Кассирер Э. Философия символических форм. В 3-х томах. М., СПб.: Университетская книга, 2002.

[10] Кафка Ф. Замок. Ростов-на-Дону: Феникс, 1999.

[11] Леви-Брюль Л. Сверхъестественное в первобытном мышлении. М.: Педагогика-Пресс, 1999.

[12] Леви-Стросс К. Структурная антропология. М.: Эксмо, 2001.

[13] Лосев А.Ф. Античная мифология. М.: Эксмо, 2005.

[14] Малиновский Б. Научная теория культуры. М.: ОГИ, 2005.

[15] Пропп В. Исторические корни волшебной сказки. М.: Лабиринт, 1998.

[16] Сорокин В. Собрание сочинений в 2 т. М.: Ad Marginem, 1998.

[17] Фрейденберг О. М. Поэтика сюжета и жанра. М.: Лабиринт, 1997.

[18] Фрезер Дж. Золотая ветвь. М.: Политическая литература, 1983.

[19] Фрейд 3. Тотем и табу. М.: Азбука классика, 2005.

[20] Фуко М. Воля к истине: по ту сторону знания, власти и сексуальности. М.: Ренессанс, 1996.

[21] Юнг К.Г. Архетип и символ. М: Ренессанс, 1991.

[22] Юнг К.Г. Бог и бессознательное. М.: Олимп, 1998.

[23] Юнг К.Г. Психологические типы. М.: Прогресс-Универс, 1995.

\section{Сведения об авторе:}

Стрельник Ольга Николаевна - кандидат философских наук, доцент кафедры онтологии и теории познания Российского университета дружбы народов (e-mail: ostrelnik@mail.ru) 